\title{
Corrigendum: Estimating the proportion of variation in susceptibility to schizophrenia captured by common SNPs
}

S Hong Lee, Teresa R DeCandia, Stephan Ripke, Jian Yang, The Schizophrenia Psychiatric Genome-Wide Association Study Consortium (PGC-SCZ), The International Schizophrenia Consortium (ISC), The Molecular Genetics of Schizophrenia Collaboration (MGS), Patrick F Sullivan, Michael E Goddard, Matthew C Keller, Peter M Visscher \& Naomi R Wray

Nat. Genet. 44, 247-250 (2012); published online 19 February 2012; corrected after print 15 May 2012

In the version of this article initially published, the citation for the $\mathrm{CNS}^{+}$gene set was incorrectly given as reference 17 . The correct reference (Raychadhuri et al.) has been added as reference 28 in the HTML and PDF versions of the article.

\section{Corrigendum: Ascorbic acid prevents loss of DIk1-Dio3 imprinting and facilitates generation of all-iPS cell mice from terminally differentiated B cells}

Matthias Stadtfeld, Effie Apostolou, Francesco Ferrari, Jiho Choi, Ryan M Walsh, Taiping Chen, Steen S K Ooi, Sang Yong Kim, Timothy H Bestor, Toshi Shioda, Peter J Park \& Konrad Hochedlinger

Nat. Genet. 44, 398-405 (2012); published online 4 March 2012; corrected online 18 March 2012; corrected after print 15 May 2012

In the version of this article initially published, there were errors in the units shown on the $x$ axis of Figure 2e. These errors have been corrected in the HTML and PDF versions of the article.

\section{Corrigendum: A genome-wide association study identifies susceptibility loci for Wilms tumor}

Clare Turnbull, Elizabeth R Perdeaux, David Pernet, Arlene Naranjo, Anthony Renwick, Sheila Seal, Rosa Maria Munoz-Xicola, Sandra Hanks, Ingrid Slade, Anna Zachariou, Margaret Warren-Perry, Elise Ruark, Mary Gerrard, Juliet Hale, Martin Hewitt, Janice Kohler, Sheila Lane, Gill Levitt, Mabrook Madi, Bruce Morland, Veronica Neefjes, James Nicholdson, Susan Picton, Barry Pizer, Milind Ronghe, Michael Stevens, Heidi Traunecker, Charles A Stiller, Kathy Pritchard-Jones, Jeffrey Dome, Paul Grundy \& Nazneen Rahman Nat. Genet. 44, 681-684 (2012); published online 29 April 2012; corrected after print 6 June 2012

In the version of this article initially published, the name of one of the authors was incorrectly listed as James Nicholdson. The correct name is James Nicholson. The error has been corrected in the HTML and PDF versions of the article. 